Brief Report

\title{
Comparison of Nitrogen Depletion and Repletion on Lipid Production in Yeast and Fungal Species
}

\author{
Shihui Yang ${ }^{1, *,+}$, Wei Wang ${ }^{2, *}$, Hui Wei ${ }^{2}$, Stefanie Van Wychen ${ }^{1}$, Philip T. Pienkos ${ }^{1}$, \\ Min Zhang ${ }^{1}$ and Michael E. Himmel ${ }^{2}$ \\ 1 National Bioenergy Center, National Renewable Energy Laboratory, Golden, CO 80401, USA; \\ Stefanie.VanWychen@nrel.gov (S.V.W.); Philip.Pienkos@nrel.gov (P.T.P.); Min.Zhang@nrel.gov (M.Z.) \\ 2 Biosciences Center, National Renewable Energy Laboratory, Golden, CO 80401, USA; \\ Hui.Wei@nrel.gov (H.W.); Mike.Himmel@nrel.gov (M.E.H.) \\ * Correspondence: shhyoung@hotmail.com (S.Y.); Wei.Wang@nrel.gov (W.W.); Tel.: +1-303-906-2872 (S.Y.) \\ + Current address: Hubei Collaborative Innovation Center for Green Transformation of Bio-resources, \\ Hubei Key Laboratory of Industrial Biotechnology, College of Life Sciences, Hubei University, \\ Wuhan 430062, China.
}

Academic Editor: Thomas E. Amidon

Received: 18 June 2016; Accepted: 24 August 2016; Published: 29 August 2016

\begin{abstract}
Although it is well known that low nitrogen stimulates lipid accumulation, especially for algae and some oleaginous yeast, few studies have been conducted in fungal species, especially on the impact of different nitrogen deficiency strategies. In this study, we use two promising consolidated bioprocessing (CBP) candidates to examine the impact of two nitrogen deficiency strategies on lipid production, which are the extensively investigated oleaginous yeast Yarrowia lipolytica, and the commercial cellulase producer Trichoderma reesei. We first utilized bioinformatics approaches to reconstruct the fatty acid metabolic pathway and demonstrated the presence of a triacylglycerol (TAG) biosynthesis pathway in Trichoderma reesei. We then examined the lipid production of Trichoderma reesei and Y. lipomyces in different media using two nitrogen deficiency strategies of nitrogen natural repletion and nitrogen depletion through centrifugation. Our results demonstrated that nitrogen depletion was better than nitrogen repletion with about 30\% lipid increase for Trichoderma reesei and Y. lipomyces, and could be an option to improve lipid production in both oleaginous yeast and filamentous fungal species. The resulting distinctive lipid composition profiles indicated that the impacts of nitrogen depletion on yeast were different from those for fungal species. Under three types of $\mathrm{C} / \mathrm{N}$ ratio conditions, $\mathrm{C} 16$ and $\mathrm{C} 18$ fatty acids were the predominant forms of lipids for both Trichoderma reesei and Y. lipolytica. While the overall fatty acid methyl ester (FAME) profiles of Trichoderma reesei were similar, the overall FAME profiles of $Y$. lipolytica observed a shift. The fatty acid metabolic pathway reconstructed in this work supports previous reports of lipid production in T. reesei, and provides a pathway for future omics studies and metabolic engineering efforts. Further investigation to identify the genetic targets responsible for the effect of nitrogen depletion on lipid production improvement will facilitate strain engineering to boost lipid production under more optimal conditions for productivity than those required for nitrogen depletion.
\end{abstract}

Keywords: advanced biofuel; lipids; nitrogen depletion; nitrogen repletion; Trichoderma reesei; Yarrowia lipolytica

\section{Introduction}

Bacteria, yeast, and fungi can naturally synthesize fatty acids, isoprenoids, or polyalkanoates for energy storage. These compounds have high energy densities and are compatible with current fuel infrastructure, permitting their exploitation for hydrocarbon fuel production [1-4]. Consolidated 
bioprocessing (CBP) is a promising strategy for economical lignocellulosic biofuel production, which biologically integrates enzyme production, saccharification, and fermentation. In general, two strategies have been utilized for CBP strain development, which are called "native" and "recombinant" strategies. A native strategy increases the fuel productivity of a naturally cellulolytic microorganism, whereas a recombinant strategy enables a microbe with excellent productivity with monomeric sugars to utilize lignocellulosic biomass directly $[5,6]$. The conventional/model yeast Saccharomyces cerevisiae and the oleaginous yeast Yarrowia lipolytica are excellent candidates for the recombinant strategy to enable lignocellulosic assimilation capability. Recently, National Renewable Energy Laboratory (NREL) scientists proposed a native fungal CBP platform using the model fungal cellulase producer, Trichoderma reesei [7].

Y. lipolytica is an oleaginous yeast that has been well-studied for its genetic and physiological properties [8]. Y. lipolytica genome sequence annotation $[9,10]$ and the development of versatile genetic tools [11-15]) make it suitable for metabolic engineering. In addition, Y. lipolytica is capable of metabolizing various substrates (e.g., glucose, glycerol, and wastes of animal fats and crude oils) to lipids, which can be extracted and exploited as an alternative for biofuel production [16]. Thus, unsurprisingly, the application of engineered $Y$. lipolytica has increased recently for biofuel production [17-20]. Furthermore, recent progress in expressing key cellulases, xylanases, and beta glucosidases in this organism may eventually lead to the development of a CBP oleaginous yeast strain that would permit direct utilization of biomass as carbon source and thus could further reduce the cost of culturing this organism [21-24].

The filamentous fungus, T. reesei, is a primary producer of cellulases with efficient systems for cellulase induction and nutrient transportation [25]. It possesses at least three classical enzymes: exoglucanases (syn. cellobiohydrolases), endoglucanases, and $\beta$-D-glucosidases. Other key enzymes involved in cellulose degradation have been recently identified, such as GH61 lytic polysaccharide monooxygenases (LPMOs, now classified as AA9), expansin-like proteins including swollenin (SWOI), and the expansin/family 45 endoglucanase-like proteins (EEL1, EEL2, and EEL3) [26-28]. The regulation of cellulases production in Trichoderma reesei is complex with various transcriptional factors (TFs) controlling cellulase gene expression discovered (e.g., XYR1, CRE1, ACE1, ACE2, AreA, $\mathrm{BglR}$, and HAP2/3/5 complex) [27,29-36]. Additionally, the environmental conditions for cellulase induction have also been investigated, with several inducers identified. These inducers include cellulose, disaccharides of cellobiose, lactose and sophorose, and low-molecular weight compounds, such as L-arabitol and L-sorbose [37,38]. Trichoderma reesei has been reported to have $16 \%$ to $32 \%$ $(\mathrm{w} / \mathrm{w})$ total lipid production [39-42] highlighting its potential for being engineered into an oleaginous organism, although caution should be taken for the lipid content values reported from different laboratories with different methods.

Multiple strategies have been proposed for overproducing storage lipids in various microorganisms. Among them, one major strategy is the metabolic engineering by up- and/or down-regulating several important rate-limiting enzymes or key pathways to channel carbon flux towards lipid accumulation. The reported target genes are involved in glycolysis, TCA cycle, fatty acid biosynthesis, storage lipids or triacylglycerol biosynthesis, and beta oxidation [18,19,43-45]. Another major strategy is the optimization of growth conditions, including agitation, aeration, $\mathrm{pH}$, and temperature [46-49]. Optimization of the medium, such as its $\mathrm{C} / \mathrm{N}$ ration, has also been broadly reported to affect the lipid production of oleaginous yeasts [50-52]. Nitrogen (N)-depletion has been reported as an effective approach for lipid production improvement in algal species [53-56]. Recently, a few reports also suggested that nitrogen depletion in oleaginous yeast could increase lipid production [57-59]. However, the impact of different nitrogen deficiency strategies on lipid production in yeast and filamentous fungi are thus far unreported in literature.

The goals of this study are to fill this nutritional knowledge gap, assess the effectiveness of changing the $\mathrm{C} / \mathrm{N}$ ratio, and apply the $\mathrm{N}$-depletion concept on the lipid production of two potential CBP candidates of Trichoderma reesei and Y. lipolytica. To fulfill these goals, we first conducted genome analysis to identify the genes involved in the triacylglycerol (TAG) biosynthesis pathway in 
Trichoderma reesei and then examine the lipid production of both Trichoderma reesei and Y. lipolytica in different media. We also validated the $\mathrm{N}$-depletion approach for lipid production improvement in both oleaginous yeast and fungal species.

\section{Results and Discussion}

\subsection{Reconstruction of TAG Biosynthesis Pathway in Trichoderma reesei by Genomic Metabolic Pathway Analysis}

Even though engineering the TAG biosynthesis pathway has been the focus of Y. lipolytica studies $[17-19,60,61]$, this pathway is not well understood in T. reesei. We have recently reported the genome re-annotation and reconstruction of glycolysis and fermentation; as well as terpenoid biosynthesis pathways in Trichoderma reesei [62]. The same approach was used in this study to reconstruct the fatty acid metabolism and TAG biosynthesis pathway in Trichoderma reesei (Figure 1). Similar to previous results, multiple hits from the Blast result were identified for several enzymes in fermentation and terpenoid biosynthesis pathways. Additionally, multiple genes that may play a role in encoding fatty acid metabolism enzymes of in Trichoderma reesei were identified.

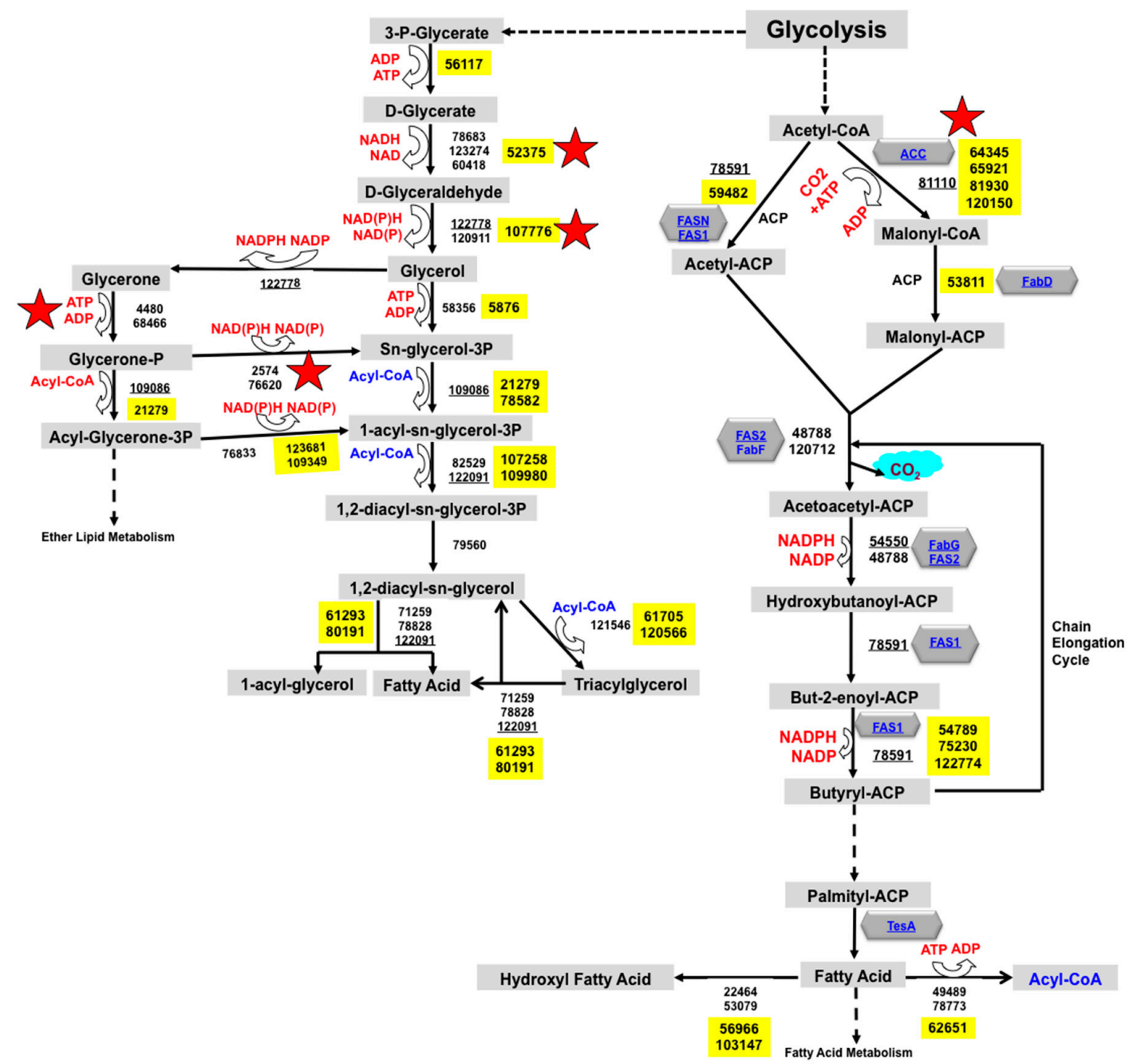

Figure 1. The reconstructed fatty acid metabolism pathway in Trichoderma reesei. Enzymes are represented by gray diamond boxes. The number(s) adjacent to enzyme represent the homologous proteins ID number identified in Trichoderma reesei genome with yellow highlight indicating reasonable similarity to homologous proteins. Multiple numbers were included for enzyme with multiple homologues. Example reactions discussed are marked by a red star. 
However, none of the genes identified have separate functional domains as subunits of a functional enzyme complex and nearly all the genes encoding an enzyme are potential paralogues with commonly conserved protein domains. For example, besides Trire 1 81110, which bears a high degree of similarity to the acetyl-CoA carboxylase (ACC) enzyme, gene products of other transcripts (Trire2 I64345, Trire2 I 65921, Trire2 |81930, and Trire2 | 120150) were also potential homologues to ACC enzyme (Figure 1). Trire2 | 78683, Trire2 | 123274, Trire2 | 60418, and Trire2 I 52375 all contain the same conserved NAD $(\mathrm{P})^{+}$-dependent aldehyde dehydrogenase superfamily (ALDH-SF) domain. Trire2 | 4480 and Trire2 168466 encode glycerone kinase with the same dihydroxyacetone kinase family domain, and glycerol dehydrogenase encoded by Trire2 | 122778, Trire2 | 120911, or Trire2 | 107776 has a similar Aldo-keto reductases (AKRs) superfamily domain. An exceptional case is the glycerol-3-phosphate dehydrogenase encoded by Trire2 | 2574 and Trire2 | 76620, which have a different cofactor of NAD or FAD preference, respectively.

The demonstrated existence of TAG biosynthesis pathway in the genome of Trichoderma reesei not only supports the previous lipid production phenotype in Trichoderma reesei [47-50], but also provides a pathway background for physiological study.

\subsection{Lipid Production by Yarrowia lipolytica in Different Media}

Since the $\mathrm{C} / \mathrm{N}$ ratio is considered to play an important role in lipid accumulation in oleaginous yeasts, the lipid profiles of Y. lipolytica in different media were first investigated. The investigation analyzed three different media types, including (1) regular YPD containing totally $30 \mathrm{~g} / \mathrm{L}$ of yeast extract and peptone, (2) YPD with less nitrogen containing totally $10 \mathrm{~g} / \mathrm{L}$ of yeast extract and peptone, and (3) a mineral medium (MM) containing only $0.5 \mathrm{~g} / \mathrm{L}$ of ammonia sulfate supplemented with $0.5 \mathrm{~g} / \mathrm{L}$ of yeast extract. As shown in Figure 2, a slight adjustment of the $\mathrm{C} / \mathrm{N}$ ratio in the YPD medium did not cause significant changes to lipid production. The mineral medium had a $\mathrm{C} / \mathrm{N}$ ratio at least 10 times higher than the YPD medium, but the FAME content of the cells growing on the mineral medium only increased by $30 \%$. This result suggests that, although a high $\mathrm{C} / \mathrm{N}$ ratio with less nitrogen in the medium can benefit lipid accumulation, it is likely to limit cell growth and therefore affect the final lipid titer. Thus, a new strategy to enhance lipid production without sacrificing healthy cell growth is needed. To this end, nitrogen depletion combined with an enrichment step on those mediums containing a low $\mathrm{C} / \mathrm{N}$ ratio before nitrogen depletion might prove effective. Besides Y. lipolytica, we also included the fungal CBP candidate, T. reesei, to examine two nitrogen deficiency strategies on lipid accumulation in these two potential CBP candidates.

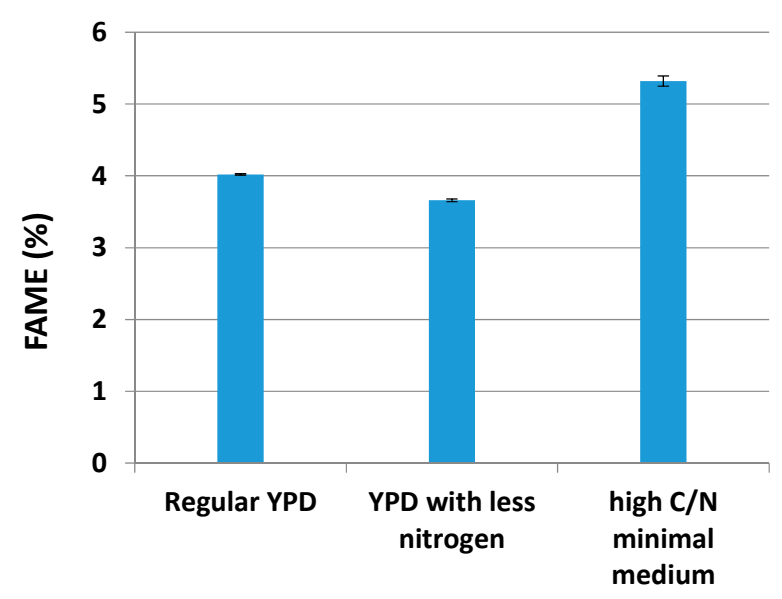

Figure 2. Lipid production by Yarrowia lipolytica in YPD and minimal media with different $\mathrm{C} / \mathrm{N}$ ratios. Total lipid content in biomass was expressed as fatty acid methyl esters (FAME). Data show mean value with standard deviation from technical triplicate samples of one representative experiment. The difference among three conditions is significant based on One Way Analysis of Variance (ANOVA) with p-value less than 0.001 for all comparisons. 


\subsection{Effects of Two Nitrogen Deficiency Strategies on Lipid Production Yield}

This investigation revealed that the color of the Trichoderma reesei culture varied when grown in a medium containing a high $\mathrm{C} / \mathrm{N}$ ratio versus one containing a low $\mathrm{C} / \mathrm{N}$ ratio. Two days post spore inoculation, the high $\mathrm{C} / \mathrm{N}$ ratio culture turned yellow; the yellow color darkened 3 days after inoculation, while the low $\mathrm{C} / \mathrm{N}$ ones remained white. In contrast, the nitrogen depletion at 2 days post inoculation by centrifugation and then switch to nitrogen-free minimum medium caused the cells from low $\mathrm{C} / \mathrm{N}$ medium changed to dark yellow, which was similar to that of high $\mathrm{C} / \mathrm{N}$ culture. This indicated that the $\mathrm{C} / \mathrm{N}$ ratio was significant to the physiology of Trichoderma reesei and could therefore serve as a lipid-production indicator for this strain. This result is consistent with the observation with algae [63].

In addition to the culture morphology, the FAME production of both Trichoderma reesei and Y. lipolytica were evaluated. The FAME production of Trichoderma reesei jumped from $7.9 \%$ to $13.4 \%$ after nitrogen depletion in the low $\mathrm{C} / \mathrm{N}$ ratio medium. Similarly, nitrogen depletion in the low $\mathrm{C} / \mathrm{N}$ ratio medium increased $Y$. lipolytica lipid production from $3.2 \%$ to $7.4 \%$. Furthermore, the lipid production of both Trichoderma reesei and Y. lipolytica after nitrogen depletion was higher than that of the high $\mathrm{C} / \mathrm{N}$ medium (Figure 3). In addition to enhancing lipid accumulation, nitrogen depletion also benefited cell growth due to a greater supply of nitrogen in the cell growth phase. The cell mass of Y. lipolytica grown in low $\mathrm{C} / \mathrm{N}$ medium with nitrogen depletion $(9.0 \pm 0.16 \mathrm{~g} / \mathrm{L})$ was greater than that grown in a low $\mathrm{C} / \mathrm{N}$ medium with nitrogen repletion $(5.6 \pm 0.1 \mathrm{~g} / \mathrm{L})$ and grew to almost twice the cell mass in a high $\mathrm{C} / \mathrm{N}$ medium $(4.6 \pm 0.3 \mathrm{~g} / \mathrm{L})$. The same observation was found with T. reesei, i.e., that more cell mass coupled with higher lipid content combined to increase lipid titer by a significant amount.

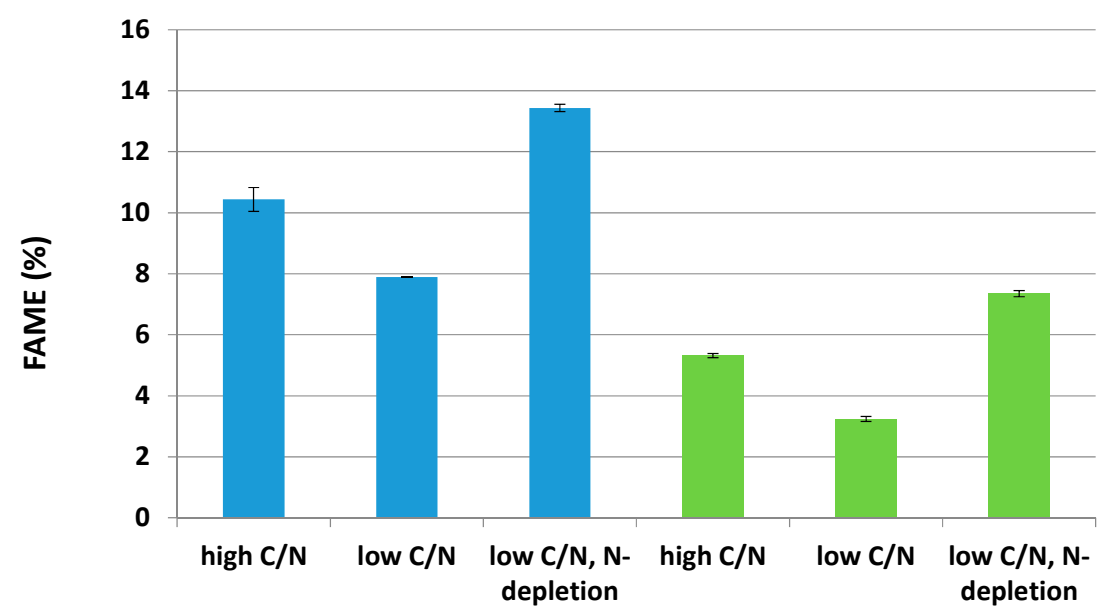

Figure 3. Lipid production of Trichoderma reesei (Blue columns) and Yarrowia lipolytica (Green columns) in different minimum media with a high $\mathrm{C} / \mathrm{N}$ ratio, low a $\mathrm{C} / \mathrm{N}$ ratio, and a low $\mathrm{C} / \mathrm{N}$ ratio with nitrogen depletion, respectively. Data show mean value with standard deviation from technical triplicate samples of one representative experiment. The difference among three conditions in each species is significant based on One Way Analysis of Variance (ANOVA) with p-value less than 0.001 for all comparisons.

The results of this investigation into lipid production of Trichoderma reesei and Y. lipolytica in different minimal media containing a high $\mathrm{C} / \mathrm{N}$ ratio, a low $\mathrm{C} / \mathrm{N}$ ratio, and a low $\mathrm{C} / \mathrm{N}$ ratio with nitrogen depletion confirmed that nitrogen depletion can enhance lipid production of both oleaginous yeast and fungal species. Further investigation however is needed to identify the most responsive genetic target in order to facilitate future strain engineering for lipid production improvement without physical nitrogen removal by centrifugation. 


\subsection{Impacts of Two Nitrogen Deficiency Strategies on the Lipid Composition Profile}

For both Trichoderma reesei and Y. lipolytica, C16 and C18 fatty acids were the predominant forms of lipids (Figure 4). However, there are two striking differences in the ways that Trichoderma reesei and Y. lipolytica responded to different $\mathrm{C} / \mathrm{N}$ ratios in the growth medium.

First, whereas the overall FAME profiles of Trichoderma reesei cultured under the three types of $\mathrm{C} / \mathrm{N}$ ratio conditions are similar in the distribution of fatty acid chain lengths (Figure 4A), the overall FAME profiles of $Y$. lipolytica grown in the three types of $\mathrm{C} / \mathrm{N}$ ratio conditions observed a shift from relative more $\mathrm{C} 16$ under high and low $\mathrm{C} / \mathrm{N}$ ratio medium conditions to more contribution from $\mathrm{C} 18$ under that of low C/N with N-depletion (Figure 4B). This contrast between Trichoderma reesei and Y. lipolytica suggests that these two species may differ in their lipid biosynthesis pathways (especially the activity of key enzymes), and also in their "fine" mechanisms for sensing N-depletion, which leads to a more dramatic reshuffling in the FAME.

Secondly, a more detailed analysis revealed that under conditions where a low $\mathrm{C} / \mathrm{N}$ ratio and nitrogen depletion was present, the lipid composition shifted to saturated forms of fatty acids for T. reesei. Y. lipolytica, in contrast, experienced a dramatic increase in its proportion of unsaturated fatty acids, especially oleic acid (C18:1n9), from approximately 20\% under high and low C/N ratio conditions to $57 \%$ when a low $\mathrm{C} / \mathrm{N}$ ratio with $\mathrm{N}$-depletion conditions was present (Figure $4 \mathrm{~B}$ ). This observation suggests the presence of an N-depletion trigger up-regulating gene expression and/or enzymatic activity of stearoyl-CoA 9-desaturase (i.e., delta 9-desaturase), which may be responsible for the biosynthesis of oleic acid from its precursor, stearoyl-CoA.

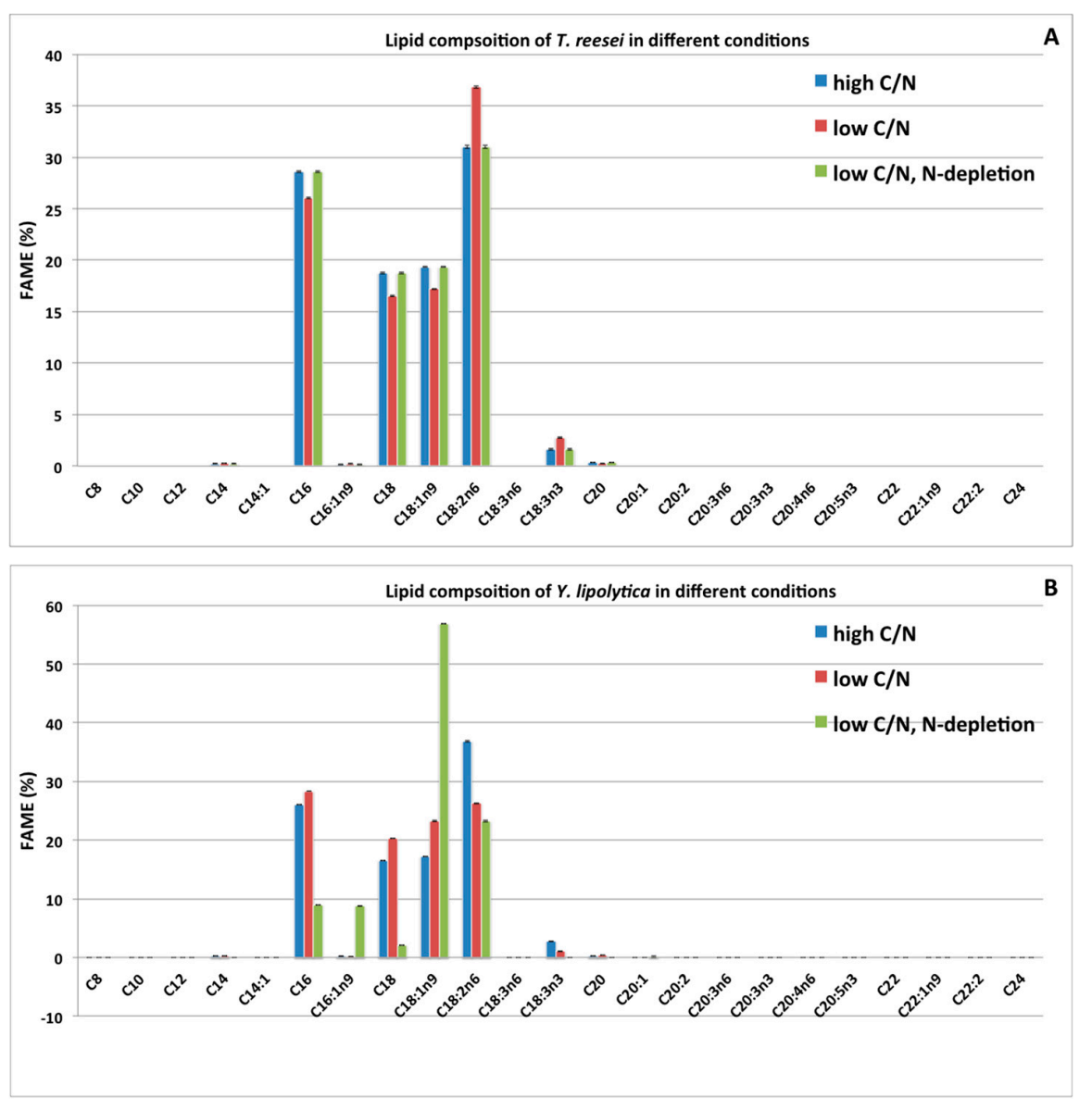

Figure 4. Lipid composition of (A) Trichoderma reesei and (B) Yarrowia lipolytica in different minimal media with a high $\mathrm{C} / \mathrm{N}$ ratio, a low $\mathrm{C} / \mathrm{N}$ ratio, and a low $\mathrm{C} / \mathrm{N}$ ratio with nitrogen depletion, respectively. Data show mean value with standard deviation from technical triplicate samples of one representative experiment. 
Together, the contrasts between Trichoderma reesei and Y. lipolytica suggest that these two species may provide a suitable pair of model microorganisms to study metabolic responses to $\mathrm{N}$-depletion at the molecular level.

\section{Materials and Methods}

\subsection{Trichoderma reesei Fatty Acid Metabolism and TAG Biosynthesis Pathway Reconstruction}

We have systematically updated the Trichoderma reesei annotation after the $34-\mathrm{Mb}$ genome sequence of Trichoderma reesei were reported and annotated in 2008 [28]. Additionally, we have reconstructed glycolysis and fermentation metabolic pathways; as well as terpenoid biosynthesis pathways [62]. A similar approach was used to reconstruct the fatty acid metabolism and TAG biosynthesis pathway in this study. 9143 protein sequences containing all manually curated and automatically annotated models chosen from the filtered models sets representing the best gene model of each locus (TreeseiV2_FrozenGeneCatalog20081022.proteins.fasta) were downloaded from JGI website (http://genome.jgi-psf.org/Trire2/Trire2.download.ftp.html). At this point, the sequences were imported into CLC Genomics Workbench (V7.0) as reference protein sequences for the Blast search. KEGG pathways, KOG, enzyme code, reaction substrate(s), and product(s) were extracted from the annotation results. The potential homologous gene(s) in Trichoderma reesei were identified by reiterated BlastP searches. Protein product and conserved domain information was examined and the pathway was reconstructed with the enzyme and pathway information obtained from literature search.

\subsection{Strain and Growth Conditions}

This work focuses on Trichoderma reesei QM6a (ATCC 13631) and Y. lipolytica Po1g (ATCC 20460 devirative, CLIB 725) [64] strains. Trichoderma reesei was revived from frozen glycerol stocks for $\sim 6-8 \mathrm{~h}$ in $10 \mathrm{~mL} \mathrm{RM}\left(10 \mathrm{~g} / \mathrm{L}\right.$ yeast extract, $\left.2 \mathrm{~g} / \mathrm{L} \mathrm{KH}_{2} \mathrm{PO}_{4}\right)+2 \%$ glucose at $33^{\circ} \mathrm{C}$ prior to inoculating overnight seed cultures in RM $+5 \%$ glucose ( $5 \%$ glucose), using shake flasks filled to $80 \%$ capacity at $33{ }^{\circ} \mathrm{C}$ at $120 \mathrm{rpm}$. When the glucose concentration reached approximately 20 to $40 \mathrm{~g} / \mathrm{L}$, cells were spun down at $3840 \times \mathrm{g}$ for $10 \mathrm{~min}$ at room temperature (RT) and resuspended in either RMG ( $8 \%$ glucose), RMX ( $8 \%$ xylose), or RMGX ( $4 \%$ glucose, $4 \%$ xylose) at 10 -fold concentration and used as inocula for fermentation studies.

Culturing of Y. lipolytica was performed in 125- and 250-mL baffled shake flasks. Seed culture was first prepared in 10-mL of regular YPD broth in $125 \mathrm{~mL}$ flask incubating at $28^{\circ} \mathrm{C}$ and $220 \mathrm{rpm}$. After $24 \mathrm{~h}, 6 \mathrm{~mL}$ of seed culture was inoculated into $50 \mathrm{~mL}$ of production media (as described below) in a 250-mL shake flask and incubated in a shaker at $28^{\circ} \mathrm{C}$ and $220 \mathrm{rpm}$. Two types of YPD media were used for lipid production by Y. lipolytica: one is regular YPD which consists of $20 \mathrm{~g} / \mathrm{L}$ glucose, $20 \mathrm{~g} / \mathrm{L}$ peptone and $10 \mathrm{~g} / \mathrm{L}$ yeast extract while the other is YPD medium with lower nitrogen, containing $20 \mathrm{~g} / \mathrm{L}$ glucose, $5 \mathrm{~g} / \mathrm{L}$ peptone and $5 \mathrm{~g} / \mathrm{L}$ yeast extract. The composition of the mineral medium is listed as in Table 1, while the experiment design for nitrogen depletion is illustrated in Figure 5.

Table 1. Minimal medium (MM) recipe used for nitrogen depletion experiments presented in Figure 5.

\begin{tabular}{ccccc}
\hline Chemical & MM & High C/N Ratio MM (g/L) & Low C/N Ratio MM (g/L) & No Nitrogen MM (N-MM, g/L) \\
\hline $\mathrm{Glucose}$ & 30 & 30 & 30 & 30 \\
$\left(\mathrm{NH}_{4}\right)_{2} \mathrm{SO}_{4}$ & 0.5 & 0.5 & 5 & 0 \\
Yeast extract & 0.5 & 1.5 & 1.5 & 0 \\
$\mathrm{KH}_{2} \mathrm{PO}_{4}$ & 7 & 7 & 7 & 7 \\
$\mathrm{Na}_{2} \mathrm{HPO}_{4}$ & 2 & 2 & 2 & 2 \\
$\mathrm{MgSO}_{4} \cdot 7 \mathrm{H}_{2} \mathrm{O}$ & 1.5 & 1.5 & 1.5 & 1.5 \\
$\mathrm{CaCl}_{2} \cdot 6 \mathrm{H}_{2} \mathrm{O}$ & 0.1 & 0.1 & 0.1 & 0.1 \\
$\mathrm{FeCl}_{3} \cdot 6 \mathrm{H}_{2} \mathrm{O}$ & 0.008 & 0.008 & 0.008 & 0.008 \\
$\mathrm{ZnSO}_{4} \cdot 7 \mathrm{H}_{2} \mathrm{O}$ & 0.0001 & 0.0001 & 0.0001 & 0.0001 \\
\hline
\end{tabular}




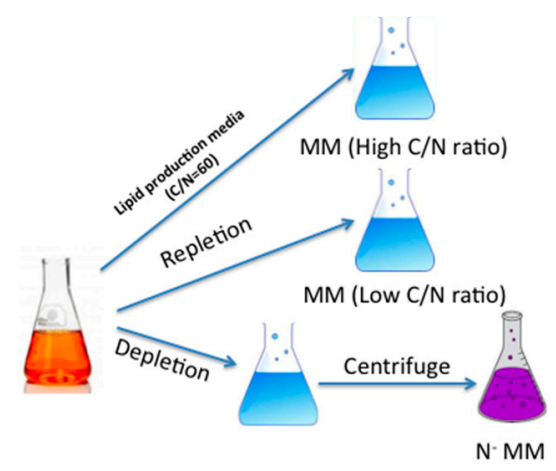

Figure 5. Experiment design to test the effect of nitrogen depletion on lipid production in Trichoderma reesei and Yarrowia lipolytica.

\subsection{Lipid Determination and Statistical Analysis}

The cell biomass was harvested at $5 \mathrm{~d}$ and then freeze dried for lipid determination using a one-step procedure as described before [65]: $0.2 \mathrm{~mL}$ chloroform-methanol $(2: 1 \mathrm{v} / \mathrm{v})$ was added to $\sim 10 \mathrm{mg}$ of lyophilized biomass to solubilize the lipids, and simultaneously transesterify the lipids in situ with $0.3 \mathrm{~mL}$ HCL-methanol $95 \% \mathrm{v} / \mathrm{v}$ for $1 \mathrm{~h}$ at $85^{\circ} \mathrm{C}$. The resulting Fatty acid methyl esters (FAMEs) were extracted with $1 \mathrm{~mL}$ hexane at room temperature for $1 \mathrm{~h}$ and analyzed by gas chromatography GC-FID (Agilent 6890N) using the DB5-MS column (Agilent, Palo Alto, CA, USA). The FAME was quantified based on the integration of individual fatty acid peaks in the chromatograms and a 5-point calibration curve of a mixed, even-carbon chain FAME standard comprised of 14 individual fatty acids (C8-C24, SIGMA cat\# 18918). The total lipid content was calculated as the sum of the even-numbered FAME contributions. Three technical replicates were used for each sample. One Way Analysis of Variance (ANOVA) of Holm-Sidak method in SigmaPlot 11.0 (Systat Software, Inc., San Jose, CA, USA) was used for the pairwise multiple comparison of the total lipid content in different growth conditions. Factor A $(P \leq 0.001)$ was selected to compare, and datasets passed both normality test and equal variance test during analysis.

\section{Conclusions}

In this study, we demonstrated the existence of a TAG biosynthesis pathway in the genome of T. reesei. The lipid production of both Trichoderma reesei and Y. lipolytica were examined in different media, and the results suggested both that nitrogen deficiency strategies enhanced the lipid production and that the nitrogen depletion strategy was better than natural nitrogen repletion, boosting lipid production further in both oleaginous yeast and fungal species. Furthermore, the data revealed that these two species responded differently to the $\mathrm{C} / \mathrm{N}$ ratio changes and $\mathrm{N}$-depletion when it came to their lipid profiling. The significant shifts in their proportions of unsaturated fatty acids may indicate potential applications for downstream lipid extracts for biodiesel and other secondary products. Further studies are needed to unravel the regulatory networks and genetic targets that play a role in the responses of yeast and filamentous fungi to nitrogen depletion. These types of studies will subsequently facilitate rational pathway engineering for lipid-producing strain development.

Acknowledgments: This work was funded by the U.S. Department of Energy's Bioenergy Technology Office (DOE-BETO) under Contract No. DE-AC36-08-GO28308 with the National Renewable Energy Laboratory (NREL). We thank Megan Krysiak for her assistance in editing the manuscript.

Author Contributions: SY designed the experiment, carried out the flask fermentation experiment, analyzed the data, and wrote the manuscript. WW designed the experiment, carried out the flask fermentation experiment, analyzed the data, and wrote the manuscript. HW designed the experiment, carried out the flask fermentation experiment, and wrote the manuscript. SVW performed the FAME and data quantification. PTP provided advice for the experiment design and comments for revision. MZ provided advice for the experiment design. MEH provided advice for the experiment design and comments for revision. All authors read and approved the final manuscript. 
Conflicts of Interest: SY is an Energies Editorial Board member. This does not alter the authors' adherence to all the Energies policies on sharing data and materials.

\section{Abbreviations}

$\begin{array}{ll}\text { CBP } & \text { consolidated bioprocessing } \\ \text { TAG } & \text { triacylglycerol } \\ \text { C/N ratio } & \text { carbon/nitrogen ratio } \\ \text { FAME } & \text { fatty acid methyl ester }\end{array}$

\section{References}

1. Peralta-Yahya, P.P.; Ouellet, M.; Chan, R.; Mukhopadhyay, A.; Keasling, J.D.; Lee, T.S. Identification and microbial production of a terpene-based advanced biofuel. Nat. Commun. 2011, 2. [CrossRef] [PubMed]

2. Peralta-Yahya, P.P.; Keasling, J.D. Advanced biofuel production in microbes. Biotechnol. J. 2010, 5, 147-162. [CrossRef] [PubMed]

3. Connor, M.R.; Liao, J.C. Microbial production of advanced transportation fuels in non-natural hosts. Curr. Opin. Biotechnol. 2009, 20, 307-315. [CrossRef] [PubMed]

4. Atsumi, S.; Hanai, T.; Liao, J.C. Non-fermentative pathways for synthesis of branched-chain higher alcohols as biofuels. Nature 2008, 451, 86-89. [CrossRef] [PubMed]

5. Hasunuma, T.; Okazaki, F.; Okai, N.; Hara, K.Y.; Ishii, J.; Kondo, A. A review of enzymes and microbes for lignocellulosic biorefinery and the possibility of their application to consolidated bioprocessing technology. Bioresour. Technol. 2013, 135, 513-522. [CrossRef] [PubMed]

6. Lynd, L.R.; Zyl, W.H.; McBride, J.E.; Laser, M. Consolidated bioprocessing of cellulosic biomass: An update. Curr. Opin. Biotechnol. 2005, 16, 577-583. [CrossRef] [PubMed]

7. Xu, Q.; Singh, A.; Himmel, M.E. Perspectives and new directions for the production of bioethanol using consolidated bioprocessing of lignocellulose. Curr. Opin. Biotechnol. 2009, 20, 364-371. [CrossRef] [PubMed]

8. Barth, G.; Gaillardin, C. Physiology and genetics of the dimorphic fungus Yarrowia lipolytica. FEMS Microbiol. Rev. 1997, 19, 219-237. [CrossRef] [PubMed]

9. Dujon, B.; Sherman, D.; Fischer, G.; Durrens, P.; Casaregola, S.; Lafontaine, I.; Montigny, J.; Marck, C.; Neuvéglise, C.; Talla, E. Genome evolution in yeasts. Nature 2004, 430, 35-44. [CrossRef] [PubMed]

10. Sherman, D.; Durrens, P.; Iragne, F.; Beyne, E.; Nikolski, M.; Souciet, J.L. Genolevures complete genomes provide data and tools for comparative genomics of hemiascomycetous yeasts. Nucleic Acids Res. 2006, 34, 432-435. [CrossRef] [PubMed]

11. Chen, D.C.; Yang, B.C.; Kuo, T.T. One-step transformation of yeast in stationary phase. Curr. Genet. 1992, 21, 83-84. [CrossRef]

12. Wang, J.H.; Hung, W.P.; Tsai, S.H. High efficiency transformation by electroporation of Yarrowia lipolytica. J. Microbiol. 2011, 49, 469-472. [CrossRef] [PubMed]

13. Davidow, L.S.; Apostolakos, D.; O’Donnell, M.M.; Proctor, A.R.; Ogrydziak, D.M.; Wing, R.A.; Stasko, I.; DeZeeuw, J.R. Integrative transformation of the yeast Yarrowia lipolytica. Curr. Genet. 1985, 10, $39-48$. [CrossRef]

14. Juretzek, T.; Dall, M.T.; Mauersberger, S.; Gaillardin, C.; Barth, G.; Nicaud, J.M. Vectors for gene expression and amplification in the yeast Yarrowia lipolytica. Yeast 2000, 18, 97-113. [CrossRef]

15. Dall, M.T.; Nicaud, J.M.; Gaillardin, C. Multiple-copy integration in the yeast Yarrowia lipolytica. Curr. Genet. 1994, 26, 38-44. [CrossRef]

16. Ratledge, C.; Wynn, J.P. The biochemistry and molecular biology of lipid accumulation in oleaginous microorganisms. Adv. Appl. Microbiol. 2002, 51, 1-51. [PubMed]

17. Beopoulos, A.; Cescut, J.; Haddouche, R.; Uribelarrea, J.L.; Molina-Jouve, C.; Nicaud, J.M. Yarrowia lipolytica as a model for bio-oil production. Prog. Lipid Res. 2009, 48, 375-387. [CrossRef] [PubMed]

18. Tai, M.; Stephanopoulos, G. Engineering the push and pull of lipid biosynthesis in oleaginous yeast Yarrowia lipolytica for biofuel production. Metab. Eng. 2013, 15, 1-9. [CrossRef] [PubMed]

19. Blazeck, J.; Hill, A.; Liu, L.; Knight, R.; Miller, J.; Pan, A.; Otoupal, P.; Alper, H.S. Harnessing Yarrowia lipolytica lipogenesis to create a platform for lipid and biofuel production. Nat. Commun. 2014, 5, 1-10. [CrossRef] [PubMed] 
20. Madzak, C. Yarrowia lipolytica: Recent achievements in heterologous protein expression and pathway engineering. Appl. Microbiol. Biotechnol. 2015, 99, 4559-4577. [CrossRef] [PubMed]

21. Boonvitthya, N.; Bozonnet, S.; Burapatana, V.; O’Donohue, M.J.; Chulalaksananukul, W. Comparison of the heterologous expression of Trichoderma reesei endoglucanase II and cellobiohydrolase II in the yeasts Pichia pastoris and Yarrowia lipolytica. Mol. Biotechnol. 2013, 54, 158-169. [CrossRef] [PubMed]

22. Wei, H.; Wang, W.; Alahuhta, M.; Wall, T.V.; Baker, J.O.; Taylor, L.E.; Decker, S.R.; Himmel, M.E.; Zhang, M. Engineering towards a complete heterologous cellulase secretome in Yarrowia lipolytica reveals its potential for consolidated bioprocessing. Biotechnol. Biofuels 2014, 7, 148. [CrossRef] [PubMed]

23. Wang, W.; Wei, H.; Alahuhta, M.; Chen, X.; Hyman, D.; Johnson, D.K.; Zhang, M.; Himmel, M.E. Heterologous expression of xylanase enzymes in lipogenic yeast Yarrowia lipolytica. PLoS ONE 2014, 9. [CrossRef] [PubMed]

24. Guo, Z.P.; Duquesne, S.; Bozonnet, S.; Cioci, G.; Nicaud, J.M.; Marty, A.; O’Donohue, M.J. Development of cellobiose-degrading ability in Yarrowia lipolytica strain by overexpression of endogenous genes. Biotechnol. Biofuels 2015, 8. [CrossRef] [PubMed]

25. Schuster, A.; Schmoll, M. Biology and biotechnology of Trichoderma. Appl. Microbiol. Biotechnol. 2010, 87, 787-799. [CrossRef] [PubMed]

26. Hakkinen, M.; Arvas, M.; Oja, M.; Aro, N.; Penttila, M.; Saloheimo, M.; Pakula, T.M. Re-annotation of the CAZy genes of Trichoderma reesei and transcription in the presence of lignocellulosic substrates. Microb. Cell Fact 2012, 11. [CrossRef] [PubMed]

27. Verbeke, J.; Coutinho, P.; Mathis, H.; Quenot, A.; Record, E.; Asther, M.; Heiss-Blanquet, S. Transcriptional profiling of cellulase and expansin-related genes in a hypercellulolytic Trichoderma reesei. Biotechnol. Lett. 2009, 31, 1399-1405. [CrossRef] [PubMed]

28. Martinez, D.; Berka, R.M.; Henrissat, B.; Saloheimo, M.; Arvas, M.; Baker, S.E.; Chapman, J.; Chertkov, O.; Coutinho, P.M.; Cullen, D. Genome sequencing and analysis of the biomass-degrading fungus Trichoderma reesei (syn. Hypocrea jecorina). Nat. Biotechnol. 2008, 26, 553-560. [CrossRef] [PubMed]

29. Dowzer, C.E.; Kelly, J.M. Cloning of the creA gene from Aspergillus nidulans: A gene involved in carbon catabolite repression. Curr. Genet. 1989, 15, 457-459. [CrossRef]

30. Ilmen, M.; Thrane, C.; Penttilä, M. The glucose repressor genecre1 of Trichoderma: Isolation and expression of a full-length and a truncated mutant form. Mol. Gen. Genet. MGG 1996, 251, 451-460. [CrossRef] [PubMed]

31. Portnoy, T.; Margeot, A.; Linke, R.; Atanasova, L.; Fekete, E.; Sandor, E.; Hartl, L.; Karaffa, L.; Druzhinina, I.S.; Seiboth, B. The CRE1 carbon catabolite repressor of the fungus Trichoderma reesei: A master regulator of carbon assimilation. BMC Genom. 2011, 12. [CrossRef] [PubMed]

32. Hynes, M. Studies on the role of the are a gene in the regulation of nitrogen catabolism in Aspergillus nidulans. Aust. J. Biol. Sci. 1975, 28, 301-314. [CrossRef] [PubMed]

33. Stricker, A.R.; Grosstessner-Hain, K.; Würleitner, E.; Mach, R.L. Xyr1 (xylanase regulator 1) regulates both the hydrolytic enzyme system and D-xylose metabolism in Hypocrea jecorina. Eukaryot. Cell 2006, 5, 2128-2137. [CrossRef] [PubMed]

34. Aro, N.; Ilmén, M.; Saloheimo, A.; Penttilä, M. ACEI of Trichoderma reesei is a repressor of cellulase and xylanase expression. Appl. Environ. Microbiol. 2003, 69, 56-65. [CrossRef] [PubMed]

35. Aro, N.; Saloheimo, A.; Ilmén, M.; Penttilä, M. ACEII, a novel transcriptional activator involved in regulation of cellulase and xylanase genes of Trichoderma reesei. J. Biol. Chem. 2001, 276, 24309-24314. [CrossRef] [PubMed]

36. Nitta, M.; Furukawa, T.; Shida, Y.; Mori, K.; Kuhara, S.; Morikawa, Y.; Ogasawara, W. A new $\mathrm{Zn}(\mathrm{II})(2) \mathrm{Cys}(6)$-type transcription factor BglR regulates beta-glucosidase expression in Trichoderma reesei. Fungal. Genet. Biol. 2012, 49, 388-397. [CrossRef] [PubMed]

37. Schmoll, M.; Kubicek, C.P. Regulation of Trichoderma cellulase formation: Lessons in molecular biology from an industrial fungus: A review. Acta Microbiol. Immunol. Hung. 2003, 50, 125-145. [CrossRef] [PubMed]

38. Nogawa, M.; Goto, M.; Okada, H.; Morikawa, Y. L-Sorbose induces cellulase gene transcription in the cellulolytic fungus Trichoderma reesei. Curr. Genet. 2001, 38, 329-334. [CrossRef] [PubMed]

39. Bhanja, A.; Minde, G.; Magdum, S.; Kalyanraman, V. Comparative studies of oleaginous fungal strains (Mucor circinelloides and Trichoderma reesei) for effective wastewater treatment and Bio-Oil production. Biotechnol. Res. Int. 2014, 2014. [CrossRef] [PubMed]

40. Brown, D.E.; Hasan, M.; Lepe-Casillas, M.; Thornton, A.J. Effect of temperature and pH on lipid accumulation by Trichoderma reesei. Appl. Microbiol. Biotechnol. 1990, 34, 335-339. [CrossRef] 
41. Brown, D.E.; Hasan, M.; Thornton, A.J. Fat production by Trichoderma reesei. Biotechnol. Lett. 1988, 10, $249-254$. [CrossRef]

42. Serrano-Carreon, L.; Hathout, Y.; Bensoussan, M.; Belin, J.M. Lipid accumulation in Trichoderma species. FEMS Microbiol. Lett. 1992, 93, 181-187. [CrossRef]

43. Dey, P.; Mall, N.; Chattopadhyay, A.; Chakraborty, M.; Maiti, M.K. Enhancement of lipid productivity in oleaginous Colletotrichum fungus through genetic transformation using the yeast CtDGAT2b gene under model-optimized growth condition. PLoS ONE 2014, 9. [CrossRef] [PubMed]

44. Liang, M.H.; Jiang, J.G. Advancing oleaginous microorganisms to produce lipid via metabolic engineering technology. Prog. Lipid Res. 2013, 52, 395-408. [CrossRef] [PubMed]

45. Courchesne, N.M.D.; Parisien, A.; Wang, B.; Lan, C.Q. Enhancement of lipid production using biochemical, genetic and transcription factor engineering approaches. J. Biotechnol. 2009, 141, 31-41. [CrossRef] [PubMed]

46. Castanha, R.F.; Mariano, A.P.; Morais, L.A.S.; Scramini, S.; Monteiro, R.T.R. Optimization of lipids production by Cryptococcus laurentii 11 using cheese whey with molasses. Braz. J. Microbiol. 2014, 45, 379-387. [CrossRef] [PubMed]

47. Papanikolaou, S.; Aggelis, G. Lipid production by Yarrowia lipolytica growing on industrial glycerol in a single-stage continuous culture. Bioresour. Technol. 2002, 82, 43-49. [CrossRef]

48. Huang, C.; Zong, M.H.; Wu, H.; Liu, Q.P. Microbial oil production from rice straw hydrolysate by Trichosporon fermentans. Bioresour. Technol. 2009, 100, 4535-4538. [CrossRef] [PubMed]

49. Kavscek, M.; Bhutada, G.; Madl, T.; Natter, K. Optimization of lipid production with a genome-scale model of Yarrowia lipolytica. BMC Syst. Biol. 2015, 9. [CrossRef] [PubMed]

50. Braunwald, T.; Schwemmlein, L.; Graeff-Honninger, S.; French, W.T.; Hernandez, R.; Holmes, W.E.; Claupein, W. Effect of different $\mathrm{C} / \mathrm{N}$ ratios on carotenoid and lipid production by Rhodotorula glutinis. Appl. Microbiol. Biotechnol. 2013, 97, 6581-6588. [CrossRef] [PubMed]

51. Huang, C.; Wu, H.; Li, R.F.; Zong, M.H. Improving lipid production from bagasse hydrolysate with Trichosporon fermentans by response surface methodology. New Biotechnol. 2012, 29, 372-378. [CrossRef] [PubMed]

52. Chaisawang, M.; Verduyn, C.; Chauvatcharin, S.; Suphantharika, M. Metabolic networks and bioenergetics of Aurantiochytrium sp. B-072 during storage lipid formation. Braz. J. Microbiol. 2012, 43, 1192-1205. [CrossRef] [PubMed]

53. Hirooka, S.; Higuchi, S.; Uzuka, A.; Nozaki, H.; Miyagishima, S.Y. Acidophilic green alga Pseudochlorella sp. YKT1 accumulates high amount of lipid droplets under a nitrogen-depleted condition at a low-pH. PLoS ONE 2014, 9. [CrossRef] [PubMed]

54. Li, Y.; Horsman, M.; Wang, B.; Wu, N.; Lan, C.Q. Effects of nitrogen sources on cell growth and lipid accumulation of green alga Neochloris oleoabundans. Appl. Microbiol. Biotechnol. 2008, 81, 629-636. [CrossRef] [PubMed]

55. Guarnieri, M.T.; Nag, A.; Yang, S.; Pienkos, P.T. Proteomic analysis of Chlorella vulgaris: potential targets for enhanced lipid accumulation. J. Proteom. 2013, 93, 245-253. [CrossRef] [PubMed]

56. Guarnieri, M.T.; Nag, A.; Smolinski, S.L.; Darzins, A.; Seibert, M.; Pienkos, P.T. Examination of triacylglycerol biosynthetic pathways via de novo transcriptomic and proteomic analyses in an unsequenced microalga. PLOS ONE 2011, 6. [CrossRef] [PubMed]

57. Seip, J.; Jackson, R.; He, H.; Zhu, Q.; Hong, S.P. Snf1 is a regulator of lipid accumulation in Yarrowia lipolytica. Appl. Environ. Microbiol. 2013, 79, 7360-7370. [CrossRef] [PubMed]

58. Sitepu, I.R.; Sestric, R.; Ignatia, L.; Levin, D.; German, J.B.; Gillies, L.A.; Almada, L.A.; Boundy-Mills, K.L. Manipulation of culture conditions alters lipid content and fatty acid profiles of a wide variety of known and new oleaginous yeast species. Bioresour. Technol. 2013, 144, 360-369. [CrossRef] [PubMed]

59. Tsigie, Y.A.; Wang, C.Y.; Truong, C.T.; Ju, Y.H. Lipid production from Yarrowia lipolytica Po1g grown in sugarcane bagasse hydrolysate. Bioresour. Technol. 2011, 102, 9216-9222. [CrossRef] [PubMed]

60. Zhu, Q.; Jackson, E.N. Metabolic engineering of Yarrowia lipolytica for industrial applications. Curr. Opin. Biotechnol. 2015, 36, 65-72. [CrossRef] [PubMed]

61. Morin, N.; Cescut, J.; Beopoulos, A.; Lelandais, G.; Le, V.; Uribelarrea, J.L.; Molina-Jouve, C.; Nicaud, J.M. Transcriptomic analyses during the transition from biomass production to lipid accumulation in the oleaginous yeast Yarrowia lipolytica. PLoS ONE 2011, 6. [CrossRef] [PubMed] 
62. Yang, S.; Wang, W.; Wei, H.; Himmel, M.E.; Zhang, M. Identification of genetic targets to improve lignocellulosic hydrocarbon production in Trichoderma reesei using public genomic and transcriptomic datasets. In Direct Microbial Conversion of Biomass to Advanced Biofuels; Himmel, M.E., Waltham, M.A., Eds.; Elsevier: Amsterdam, The Netherlands, 2015.

63. Cakmak, T.; Angun, P.; Ozkan, A.D.; Cakmak, Z.; Olmez, T.T.; Tekinay, T. Nitrogen and sulfur deprivation differentiate lipid accumulation targets of Chlamydomonas reinhardtii. Bioengineered 2012, 3, 343-346. [CrossRef] [PubMed]

64. Madzak, C.; Treton, B.; Blanchin-Roland, S. Strong hybrid promoters and integrative expression/secretion vectors for quasi-constitutive expression of heterologous proteins in the yeast Yarrowia lipolytica. J. Mol. Microbiol. Biotechnol. 2000, 2, 207-216. [PubMed]

65. Laurens, L.M.; Quinn, M.; Wychen, S.; Templeton, D.W.; Wolfrum, E.J. Accurate and reliable quantification of total microalgal fuel potential as fatty acid methyl esters by in situ transesterification. Anal. Bioanal. Chem. 2012, 403, 167-178. [CrossRef] [PubMed]

(C) 2016 by the authors; licensee MDPI, Basel, Switzerland. This article is an open access article distributed under the terms and conditions of the Creative Commons Attribution (CC-BY) license (http://creativecommons.org/licenses/by/4.0/). 